\title{
Yaşam Yöneliminin Bilişsel Davranışsal Kaçınmanın COVID-19 Korkusunu Yordayıcı Gücünün Belirlenmesi ve Çeşitli Değişkenlerle Olan İlişkilerinin İncelenmesi
}

\author{
Muhammed Ali AĞCA${ }^{1}$, Muhammed Çağrı KANDEMİR² ve Selahattin AVŞAROĞLU³ \\ Öz \\ Covid-19 salgını, bireyleri birçok yönden önemli ölçüde etkilemiştir. Bu salgının önemli etkileri arasında hiç şüphesiz \\ bireyler üzerinde oluşturmuş olduğu psikososyal etkiler de bulunmaktadır. Bu araşıırmanın temel amacı bireylerin \\ bilişsel davranışsal kaçınmalarının ve yaşam yönelimlerinin Koronavirüs korkularını yordayıcı gücünün \\ belirlenebilmesidir. Ayrıca bu üç değiş̧kenle ilişkili olabilecek çeşitli etmenlerin incelenmesi araştırmanın bir diğer \\ temel amacıdır. Bu amaçlar doğrultusunda 411 katılımcıya online form yöntemiyle BDKÖ, KKÖ, YYT-R ve Kişisel \\ Bilgi Formu uygulanmıştır. Araştırmada nicel araştırma yöntemlerinden İlişkisel Tarama Modeli kullanılmıştır. Elde \\ edilen veriler SPSS aracılığıyla ișlenmiș, Pearson Momentler Çarpımı Korelasyon Katsayısı, T Testi ve Regresyon \\ analizleri yapılmışıtır. Yapılan analizler sonucunda BDKÖ ve YYT-R puanlarının Covid-19 Korkusu Ölçeği \\ puanlarını anlamlı bir şekilde yordadığı görülmüştür. Buna ek olarak katılımcıların Koronavirüs korkuları ile \\ cinsiyetleri, tedbirlere uyum düzeyleri, tedavi gören yakına sahip olma ve uzman açıklamalarını/vaka sayılarını düzenli \\ olarak takip etmeleri arasında anlamlı ilișkiler bulgulanmıştır.
}

Anabtar Kelimeler: COVID-19 Korkusu, Yaşam Yönelimi, Bilişsel Davranışsal Kaçınma

Determining the Predictive Power of Life Orientation Cognitive Behavioral Avoidance on Fear of COVID-19 and Investigation of its Relationships with Various Variables

\section{Abstract}

The Covid-19 outbreak has significantly affected individuals in many ways. Among the important effects of this epidemic are undoubtedly the psychosocial effects on individuals. The main purpose of this research is to determine the predictive power of cognitive behavioral avoidance and life orientation of individuals on coronavirus fears. In addition, another main purpose of the study is to examine various factors that may be related to these three variables. In line with these purposes, CBAS, FCV-19S, LOT-R and Personal Information Form were applied to 411 participants using the online form method. Relational Scanning Model, one of the quantitative research methods, was used in the study. The data obtained were processed through SPSS, Pearson Product Moment Correlation Coefficient, T Test and Regression analyzes were performed. As a result of the analysis, it was seen that the scores of the CBAS and LOT-R significantly predicted the Covid-19 Fear Scale scores. In addition, significant correlations were found between participants' fear of coronavirus and their gender, their level of compliance with the measures, having relatives receiving treatment, and regularly following expert statements / case numbers.

Key Words: Fear of COVID-19, Life Orientation, Cognitive Behavioral Avoidance

\section{Atıf İçin / Please Cite As:}

Ağca, M. A., Kandemir, M. Ç. ve Avşaroğlu, S. (2022). Yaşam yöneliminin bilişsel davranışsal kaçınmanın COVID-19 korkusunu yordayıcı gücünün belirlenmesi ve çeşitli değişkenlerle olan ilişkilerinin incelenmesi. Manas Sosyal Araşttrmalar Dergisi, 11(1), 404-419.

Geliş Tarihi / Received Date: 19.01.2021

Kabul Tarihi / Accepted Date: 19.07.2021

\footnotetext{
${ }^{1}$ Yüksek Lisans Öğrencisi - Necmettin Erbakan Üniversitesi Ahmet Keleşoğlu Eğitim Fakültesi, pdmuhammedaliagca@gmail.com

(iD) ORCID: 0000-0001-8598-8887

${ }^{2}$ Yüksek Lisans Öğrencisi - Necmettin Erbakan Üniversitesi Ahmet Keleşoğlu Eğitim Fakültesi, kandemir.cgr@gmail.com

D ORCID: 0000-0003-2648-2450

${ }_{3}^{3}$ Prof. Dr. - Necmettin Erbakan Üniversitesi Ahmet Keleşoğlu Eğitim Fakültesi, seloavsar@gmail.com

(iD ORCID: 0000-0002-0953-2922
} 


\section{Giriş}

Koronavirüsler, 1960'lardan beri tanınan, isimlerini yüzeylerindeki Latince "Corona" yani "taç" benzeri yapidan alan oldukça geniş bir virüs grubudur (Struman ve Holmes, 1983, s. 37). Bu virüs grubundaki bazı virüsler yalnızca basit enfeksiyonlara neden olabilirken bazı virüsler de SARS (Severe Acute Respiratory Syndrome) ve MERS (Middle East Respiratory Syndrome) gibi insandan insana geçen ölümcül enfeksiyonlara neden olabilmektedir (Andersen, Rambaut, Lipkin, Holmes ve Garry, 2020, s. 450).

Koronavirüs ailesinden olan SARS-CoV-2 ise ilk defa 2019'un Aralık ayında Çin'in Wuhan kentinde tespit edilmiş, kısa sürede önce tüm Çin'e daha sonra da tüm ülkelere hızla yayılmışır. Türkiye'de ise ilk vaka 11 Mart'ta tespit edilmiştir (T.C. Sağlık Bakanlığı, 2020, s. 5). Tipkı SARS-CoV ve MERS-CoV gibi SARS-CoV-2 de hayvanlardan insana geçtiği düşünülen ve ciddi solunum enfeksiyonuna neden olabilen bir virüstür (Sohrabi, 2020, s. 71). Dünya Sağllk Örgütü, 11 Mart 2020'de SARS-CoV-2 virüsünün yol açtığ1 COVID-19 (Novel Coronavirus) hastalığının 114 ülkede görülmesi ve vaka sayılarının artacağ1 öngörüsüyle, Koronavirüs'ü küresel salgnn (pandemi) olarak ilan etmiştir (World Health Organization, 2020a)

Diğer ülkelerde olduğu gibi Türkiye'de de salgınla mücadele kapsamında çok sayıda önlem alınmış ve günlük hayat ciddi boyutlarda değişmiştir (TÜBA, 2020, s. 50). Covid-19 pandemisinin karmaşaya, kararsızlıklara ve belirsizliklere neden olabildiği bilinmektedir (Kırpık, 2020, s. 2402). Pandemi ve beraberinde getirdiği değişimler, bireylerin ruh sağlını da etkilemiştir (Banerjee, 2020, s. 1; Brooks vd., 2020, s. 919). Bu etkilerin başlıcaları arasında travmatik stres, depresyon, tedirginlik, yüksek düzeyde kayg1 ve korku bulunmaktadır (Dönmez ve Gürbüz, 2020, s. 2169; Khan vd., 2020, s. 2; Lima vd., 2020, s. 1; Wang vd., 2020, s. 21; Zandifar ve Badrfam, 2020, s. 1). Haktanır, Seki ve Dilmaç (2020, s. 3) kadınların Koronavirüs korkusu düzeyinin erkeklere göre daha yüksek olduğunu ve sosyoekonomik düzeyi orta olan katılımcıların sosyoekonomik düzeyi yüksek olan katılımcılardan Koronavirüs korkusu düzeyinin daha yüksek olduğunu belirtmektedir.

Ahorsu vd. (2020, s. 2) Koronavirüs korkusunun, bireylerin salgina tepkisini etkileyebileceğini ve bunun rasyonel olmayan kararlar almalarına neden olabileceğini ifade etmektedir. Ancak buna karşın gerçekçi bir kişisel risk algısının önleyici davranışlarla ilişkili olabileceğini öne süren araşırmacılar da vardır (Wise vd., 2020, s. 8). Bangladeş ve Hindistan'da iki kişinin Covid-19 olmamalarına rağmen virüs kaptıklarını düşünerek intihar etmesi (Goyal vd., 2020, s. 1; Mamun ve Griffiths, 2020, s. 1) Covid-19'un dolaylı veya doğrudan etkileri nedeniyle çok sayıda ülkeden intihar vakalarının bildirilmesi (Thakur ve Jain, 2020, s. 953) fakat öte yandan bazı çalışmaların virüs kapma ile ilgili gerçekçi risk algısının ve korkunun önleyici davranışları artırabileceğini göstermesi bu iki görüşü de doğrular niteliktedir (Harper, Satchell, Fido ve Latzman, 2020, s. 7; Wise vd., 2020, s. ; Raude vd., 2020). Lakin Harper ve arkadaşları (2020, s. 10) pandemi öncesi ruhsal bozukluğa sahip olan bireyler gibi bazı kişiler için Koronavirüs korkusunun yüksek olmasının işlevsel önleyici davranışlara yol açmayabileceğini hatta kalıcı davranış bozukluklarına neden olabileceğini dolayısıyla işlevsel endişe ya da korku ile işlev bozucu korkunun zor olsa da ayırt edilmesi gerektiğinin önemini vurgulamaktadır.

Bireyler, günlük yaşamlarında arzu edilmeyen ancak değiştirilmesi güç veya imkânsız olan çok sayıda yaşantıya uyum sağlamak durumunda kalabilmektedir. Bireylerin karşılaşılan durumlara uyum sağlamasında sahip oldukları kişilik özellikleri, duyguları ve düşünceleri önemli rol oynamaktadır. Yaşanan durumlara iyimser olarak yaklaşılması halinde uyum sağlamanın daha kolay olduğu bilinmektedir. Dolayısıyla yaşam yönelimi yani bireylerin iyimser ya da kötümser oluşu durumlara uyum sağlamayı önemli ölçüde etkileyebilmektedir (Kahleoğulları, 2017, s. 19).

İyimserlik karşlaşılan olaylarda en iyi sonucun beklenmesi ve geleceğe güvenle bakmak olarak tanımlanmaktadır (Carver, Scheier ve Segerstrom, 2010, s. 879; Gillham ve Reivich, 2004, s. 147). Baz1 kuramcılar iyimserliği bireylerin karşılaştıkları durum ve olayları açıklama tarzı olarak ele alırken (Seligman ve Schulman, 1986, s.832) bazı kuramcılar ise iyimserliği içinde bulunulan olay ve durumdan bağımsız olarak bir kişilik özelliği olarak ele almıştır (Scheier ve Carver, 2002, s. 233). Bu çalışmada da iyimserlik bahsedilen ikinci tanımda olduğu gibi genel bir eğilim olarak ele alınmaktadır.

İyimserlik düzeyi yüksek bireylerin; nevrotik eğilimlerinin düşük olduğu (Darwill ve Johnson, 1991, s. 954), kötümserlere nazaran daha az sağlık sorunu yaşadığ1 (Aydın ve Tezer, 1991, s. 7), daha çok problem odaklı başa çıma stratejisini kullandıkları ve öfke düzeylerinin daha düşük olduğu bildirilmektedir (Puskar 
vd., 1999, s.126). Buna ek olarak iyimserliğin; mesleki tükenmişlik ve stres düzeyinin azaltılmasında önemli rol oynadığ1 (Chang, Rand ve Strunk, 2000, s. 259), zihinsel engelli çocuğu olan ebeveynlerin yaşam doyumunu yordadığı (Avşaroğlu ve Okutan, 2018, s. 71), yaşam doyumu ile sıkıntıyı tolere etme arasındaki ilişkide aracllık rolü üstlendiği (Avşaroğlu ve Koç, 2019, s. 573) ifade edilmektedir.

İyimserlik düzeyi yüksek olan bireylerin koruyucu sağlık davranışlarının kötümser bireylere göre daha fazla olduğu (Ingledew ve Brunning, 1999, s. 200), daha az sigara kullandıkları, aşırı alkol tüketiminden kaçındıkları, fiziksel egzersizlere daha çok katıldıkları (Steptoe vd., 2006, s. 80) bildirilmektedir. Ayrıca iyimserlik düzeyi yüksek bireylerin; sağlığa ilişskin davranışlara karşı daha hassas olduğu, tedaviye katılımlarının daha yüksek olduğu (Geers vd., 2010, s. 123) ve önemli yaşam olaylarından sonra iyileşme sürelerinin daha kısa olduğu belirtilmektedir (Kivimaki vd., 2005, s. 418). Dumalaon-Canaria ve arkadaşlarının $(2018$, s. 7) iyileşen kanser hastaları arasında yaptığı çalışmaya göre iyimser bireylerin tekrar kansere yakalanma korkusu düzeyleri daha düşüktür. Nes ve Segerstrom da (2006, s. 235) iyimser bireylerin; ameliyat öncesi, ameliyat sonrası, kanser ve benzeri önemli hastalık durumlarında sıkıntı düzeylerinin daha düşük olduğunu belirtmektedir.

Buna karşın aşırı iyimserliğin ve gerçek dışı iyimserliğin birtakım tedbirsel davranışların oluşumunu engellemesi nedeniyle çeşitli riskler doğurabileceğini iddia eden araştırmacılar da vardır. Bu doğrultuda yapılmış iyimserlik ile önleyici davranışlar arasında negatif yönlü bir ilişkinin olduğunu ortaya koyan birçok araştırma bulunmaktadır (Burger ve Burns, 1988, s. 265). Tennen ve Ameck (1987, s. 383) ise, aşırı iyimserliğin bireyin kendisinin başına kötü bir şey gelebilme olasılığını diğer insanlara göre düşük görmeye neden olabileceğini öne sürerek aşırı iyimserliğin sakıncalı yönlerini ortaya koymuştur. Bu çerçevede, incinmezlik yanılsaması adı verilen bu durumun günlük hayatta gerekli olabilecek çeşitli tedbirli davranışları engelleyebileceği belirtilmektedir (Mansfield, 2007).

Bu doğrultuda, Polonya'da Koronavirüs pandemisi esnasinda Dolinski vd.'nin (2020, s. 6) yaptı̆g1 çalısmaya göre hem erkeklerde hem de kadınlarda gerçekçi olmayan iyimserlik gözlemlenmiş ve bu durumun maske kullanmama, mesafeye dikkat etmeme gibi tedbirlere yetirince uymamanin önemli bir nedeni olabileceği ifade edilmiştir. Öte yandan yine milyonlarca insanın etkilendiği SARS salgını esnasında Ji, Zhang, Usborne ve Guan (2004, s. 31) tarafindan salgının yoğun olarak yaşandığ bölgeler olan Kanada'da ve Pekin'de yapılan araştırmanın sonuçlarına göre katılımcılar gerçek dışı bir iyimserlik göstermelerine rağmen kendi enfekte olma olasılıklarını gerçeğe göre daha yüksek olarak bildirmişlerdir. $\mathrm{Bu}$ durumun olas1 nedenlerinden birisi olarak katıllmciların hasta olma olasilikların tahmin etmede daha yüksek düzeyde "savunmacı karamsarlık" sergilemeleri gösterilmektedir. Son olarak, Arslan vd.'nin (2020, s. 12) Türkiye'de yürüttüğü çalışmanın bulgularına göre, Koronavirüs stresinin psikolojik problemler üzerindeki etkisinde iyimserlik-kötümserliğin ve psikolojik esnekliğin aracıllk rolü söz konudur.

Kayg1 ve fobilerin, kökeninde ya da sürdürülmesinde kaçınmanın önemli rol oynadığı bilinmektedir (Newman ve Llera, 2011). Kaçınma; kişiye rahatsızlık veren eylem, durum, ortam veya çeşitli şeylerden uzaklaşma olarak tanımlanmaktadır (Ottenbreit ve Dobson, 2004, s. 293). Beck ve Emery'e (2019, s. 5455) göre hem bilişsel hem de davranışsal kaçınma yani kayg1 veya korku yaratan durumu düşünmemeye çalışmak ya da o ortamdan uzaklaşmak bireyin bu duygulardan kısa süreli olarak uzaklaşmasını sağlamakta bu durum da bu davranışın pekişmesine yol açabilmektedir. Ancak kaçınma, bireye kısa süreli rahatlama hissi getirse de uzun vadede kaygının ve korkunun sürdürülmesine hatta artmasına yol açmaktadır.

Literatür incelendiğinde kaçınmanın; başa çıkma stratejisi olarak, kişilik boyutu olarak ve problem çözme stili olarak 3 şekilde ele alındığı görülmektedir. Öte yandan bu çalışmada kullanılan BilişselDavranışsal Kaçınma Ölçeği ise kaçınmayı fonksiyonel olmayan duygu düzenleme stratejisi olarak ele almış ve kaçınmanın sosyal boyutunun da dâhil edilmesiyle, kaçınmayı çok boyutlu olarak incelemiştir (Ottenbreit ve Dobson, 2004, s. 294).

Domuz Gribi, SARS gibi salgınların bireylerde kaçınmayı ve kaçınmaya bağlı semptomları arttırdığı bilinmektedir (Leppin ve Aro, 2009, s. 22; Wu, Cheung ve Chan, 2005, s. 41; Goodwin, Gaines, Myers ve Neto, 2011, s. 90). Çeşitli ülkelerde yapılan araştırmalar; bireylerin Koronavirüs dişında farklı bir nedenle tedaviye ihtiyaç duymalarına rağmen tedaviden kaçınabildiklerini (Ganson, Weiser, Tsai ve Nagata, 2020, s. 3406), Koronavirüs kaygisı ile Çin yemeklerinden ve ürünlerinden kaçınma arasındaki pozitif korelasyonu (Lee, 2020, s. 399), Koronavirüs pandemisi esnasında gerekli tedbirlerin ötesinde aşırı güvenlik arama davranışları gösterilebildiğini (Shabahang, 2020, s. 91), Koronavirüs pandemisinde Bilişsel-Davranışsal kaçınmanın psikolojik sıkıntının en önemli yordayıcısı olduğunu (Zimmermann, Bledsoe ve Papa, 2020, s. 
29), deneyimsel kaçınmanın COVID-19 korkusunun OKB üzerindeki etkisinde aracllık rolü üstlendiği bildirilmektedir (Seçer ve Ulaş, 2020, s. 11).

Ancak fonksiyonel olmayan bilişsel-davranışsal kaçınma ile salgından korunmak için gerekli olan birtakım önemli ve işlevsel tedbirlerin karıştırlmaması gereklidir. Yani el hijyenine dikkat edilmesi, sosyal mesafeye dikkat edilmesi ve sosyal alanlarda maske kullanımı gibi salgindan koruma bakımından fonksiyonel olan tedbirler bilişsel-davranışsal kaçınma olarak görülmemelidir. Bireylerin iyimserlik/karamsarlık düzeylerinin ve bilişsel-davranışsal kaçınma düzeylerinin Koronavirüs korkularını yordayabileceği fikrinden hareketle literatüre aşağıda belirtilen amaçlar doğrultusunda katkı sağlanabileceği düşünülmektedir.

$\mathrm{Bu}$ araştırmanın amac1, Covid-19 sürecinde bireylerin yaşam yönelimleri, bilişsel davranışsal kaçınma düzeyleri ve Koronavirüs korkuları arasındaki yordayıcı ilişkileri ve bunlarla ilişkili olabileceği düşünülen çeşitli değişkenlerle olan ilişkileri ortaya çıkartmaktır. Bu ana amaçtan yola çıkarak aşağıdaki alt amaçlar doğrultusunda araştırma yürütülmüştür.

1. Bireylerin Covid-19 korkuları cinsiyetlerine göre anlamlı bir şekilde farklılaşmakta mıdır?

2. Bireylerin hastanede Covid-19 nedeniyle tedavi gören yakına sahip olma durumlarına göre Koronavirüs korkuları ve hastanede tedavi görebileceklerini düşünme sıklıkları anlamlı bir şekilde farklılaşmakta mıdır?

3. Bireylerin tedavi sürecine tanık olma durumlarına göre tedbir düzeyleri anlamlı bir şekilde farklılaşmakta mıdır?

4. Bireylerin kitle iletişim araçlarından doktorların açıklamalarını düzenli takip etme durumlarına göre Koronavirüs korkular1, tedbirlere uyum düzeyleri ve Covid-19 nedeniyle hastanede tedavi görebileceklerini düşünme sıklıkları anlamlı bir şekilde farklılaşmakta mıdır?

5. Bireylerin Koronavirüs salgını sırasında televizyon ve diğer kitle iletişim araçlarından açıklanan vaka sayılarını düzenli takip edip etmeme durumlarına göre YYT-R, KKÖ, BDKÖ, Koronavirüs karşı önerilen başlıca tedbirlere (el hijyeni, sosyal mesafe, maske) uyma düzeyleri ve Koronavirüs nedeniyle hastanede tedavi göreceklerini düşünme düzeyleri anlamlı bir şekilde farklılaşmakta midir?

6. Bireylerin BDKÖ, YYT-R, KKÖ puanları, yaş ve tedbirlere uyum düzeyleri arasında anlamlı bir ilişki var mıdır?

7. Bireylerin yaşam yönelimleri ve bilişsel davranışsal kaçınmaları, Covid-19 korkularını anlamlı bir şekilde yordamakta mıdır?

\section{Yöntem}

Araştırma amacına yönelik olarak katılımcıların Koronavirüs korkuları, yaşam yönelimleri, bilişsel davranışsal kaçınma düzeyleri ve çeşitli değişkenler arasındaki ilişkilerin ortaya çıkarılabilmesi adına ilişkisel tarama modeline başvurulmuştur. Korelasyonel araştırma en az iki değişken arasındaki ilisskilerin, değişkenlere müdahale edilmeksizin incelendiği türden araştırmalardır (Büyüköztürk vd., 2016, s. 185).

\section{Araştırmanın Çalışma Grubu}

Araştırmanın çalışma grubunu Covid-19 virüsü salgını sürecinde online olarak araştırmaya katılmaya gönüllü olan 18 yaş ve üzerinde, Türkiye'nin 63 ilinden 411 katılımcı oluşturmaktadır. Katılımciların \%55'lik kısmını ( $\mathrm{n}=226)$ kadın katılımcilar, \%45'lik kısmını ( $\mathrm{n}=185)$ ise erkek katılımcilar oluşturmaktadır. Araştırmaya katılan bireylerin yaş ortalaması ise 31,9 olarak hesaplanmıştır.

\section{Veri Toplama Araçları}

Covid-19 Korkusu Ölçeği: Covid-19 Korkusu Ölçeği, Ahorsu vd. (2020) tarafindan geliştirilen tek boyutlu 5'li likert tipinde 7 maddelik bir ölçektir. Ölçekten alınan puanın yüksekliği Koronavirüs korkusunun yüksekliğini bildirmektedir. Ölçekten en yüksek 35 puan, en düşük 7 puan alınabilmektedir. Ahorsu vd. (2020) madde-toplam korelasyonlarının 0,47 ile 0,56 arasında değiştiğini ve maddelerin faktör yüklerinin 0,66 ile 0,74 arasında değişmekte olduğunu bildirmiştir. Ölçeğin iç tutarll1lğı 0,82 ve bileşik güvenirliği 0,88'dir. Ölçeğin Türkçe uyarlaması ve geçerlilik çalışması Haktanır, Seki ve Dilmaç (2020) tarafindan yapılmıştır. Araştırmacılar, Koronavirüs korku ölçeğinin güvenilirliğini belirlemek için iç tutarlılık ve yarıya bölme analizleri gerçekleştirmiş, analizler sonucunda Cronbach alfa katsayısını 0.86 olarak tespit etmiştir. Ölçeğin Türkçe versiyonunun maddelerinin faktör yükleri 0,50 ile 0,081 arasinda değişmekte olduğu bildirilmektedir. Sonuç olarak ölçeğin Türkçe versiyonun orijinal formda olduğu gibi 
tek faktörlü 7 maddelik yapıda olduğu ve Türkçe konuşan grupların Koronavirüs korkularının ölçümlenebilmesi için geçerli olduğu bildirilmektedir.

Yaşam Yönelim Testi Revize: Yaşam Yönelim Testi Revize Versiyonu; Carver, Scheier, Bridges (1994) tarafindan geliştirilmiş bireylerin iyimserlik ve karamsarllk düzeylerinin ölçümlenebilmesini amaçlayan 10 maddelik 5'li likert tipi bir ölçektir. Ölçeğin 2., 5., 6. ve 8. maddesi dolgu maddeleri olması nedeniyle puanlanmamaktadır. 3., 7. ve 9. maddeler ise ters puanlamaktadır. Ölçek için kesme puanı söz konusu olmayıp alınan puanların yüksekliği iyimserliği, düşüklüğü ise karamsarllğı göstermektedir. Ölçeğin orijinal versiyonun Cronbach alfa iç tutarlılık katsayısı dolgu maddeleri dışındaki 6 madde için 0.78 olarak belirlenmiştir. Test - tekrar test analizleri neticesinde korelasyon katsayısının 0.68 ile 0.56 arasında olduğu bildirilmektedir. Ölçeğin Türkçe uyarlaması ise Kahleoğulları (2017) tarafından yapılmıştır. Araştırmacı, test - tekrar test analizine göre güvenilir bir ölçek olduğunu ancak Cronbach alfa iç tutarlılık katsayısının üniversite öğrencileri örneklemi için yeterli düzeyde olmadığını belirtmektedir. Çalışmamızda ise daha geniş bir yaş grubundan oluşan çalışma grubuna uygulanan Yaşam Yönelim Testi Revize'nin Cronbach alfa iç tutarlılık katsayısı 0.62 olarak bulunmuştur. Kilıç’a (2016, s. 48) göre Cronbach alfa iç tutarlılık katsayısının 0.60 'n üzerinde olması ölçeğin iç tutarlılı̆ının yeterli ve orta düzeyde olduğunu göstermektedir.

Bilişsel-Davranıssal Kaçınma Ölçeği: Bilişsel-Davranışsal Kaçınma Ölçeği, Ottenbreit ve Dobson (2004) tarafindan geliştirilmiş 5’li likert tipinde 31 maddelik bir öz bildirim ölçeğidir. Ölçeğin her bir maddesi, 5 "Benim için tamamen doğru", 1 "Benim için tamamen yanlış" şeklinde puanlanmaktadır. Dolayısıyla ölçekten alınan yüksek puanlar kaçınma düzeyinin ne kadar yüksek olduğunu bildirmektedir. Ölçekte ters madde bulunmamaktadır. Ölçekte; davranışsal sosyal kaçınma, davranışsal sosyal olmayan kaçınma, bilişsel sosyal kaçınma ve bilişsel sosyal olmayan kaçınma olmak üzere 4 alt boyut bulunmaktadır. Ölçeğin Cronbach alfa iç tutarlılık katsayısı 0.91 , Test-tekrar test güvenilirliği 0.92 olarak tespit edilmiştir. Ölçeğin Türkçe uyarlaması Çakır (2016) tarafindan yapılmıştır. Ölçeğin Türkçe uyarlamasında da özgün formda olduğu gibi 4 alt boyut bulunmakta ancak farklı olarak ölçekte 31 madde yerine 29 madde bulunmaktadır. Yani 2 madde ölçek dışı bırakılmıştır. Ölçeğin güvenilirlik katsayısının 0.92 olduğu, Test - tekrar test güvenilirliğinin ise 0.60-0.90 arasında değişmekte olduğu tespit edilmiştir.

Kişisel Bilgi Formu: Katılımcılara ait demografik bilgilerin ve bu bilgilere ek olarak araştırmanın amacına yönelik çeşitli verilerin elde edilebilmesi için araştırmacılar tarafindan bu araştırmaya özgü olarak hazırlanan Kişisel Bilgi Formu kullanılmıştır. Form içerisinde toplanan bilgiler arasında katılımcıların yaşları, cinsiyetleri, medeni durumları, çocuk sayıları, bulundukları şehir, eğitim durumları, gelir düzeyleri, ev dışında çalışıp çalışmadıkları, risk grubunda olup olmadıkları ve yaşadıkları evde kendileri dışında yüksek risk grubunda bireyin bulunup bulunmadığı sorulmuştur. Bunların yanında yine araştırmanın amacına yönelik olarak tedbirlere uyum düzeyleri, sürecin başına göre aldıkları tedbirlerde değişim olup olmadığ1, Koronavirüs nedeniyle hastanede tedavi görebileceklerini düşünme sıklığı, salgının ne zaman sona ereceği, yakın çevrede vakaya tanık olma, kitle iletişim araçlarından vaka sayıları ve doktor açıklamalarını takip etme durumları hakkında bilgiler katıllımcılardan istenmiştir.

\section{Verilerin Analizi}

Katıllımcılar araştırmanın başında gönüllü olduklarını ve istedikleri taktirde araştırmayı yarım bırakabileceklerini aktaran açıklama ile bilgilendirilmiş, ardından onayları alınarak yukarıda belirtilen veri toplama araçları doldurmaları istemiştir. Katılımcılar tüm soruları yanıtlamak için ortalama 15 dakika harcamışlardır. Online olarak toplanan verilerin incelenebilmesi amacıyla SPSS aracilığılla T Testi, Pearson Momentler Korelasyon Katsayısı, Çoklu Regresyon analizleri yapılmıştır.

\section{Bulgular}

Katıllımcılar araştırmanın başında gönüllü olduklarını ve istedikleri taktirde araştırmayı yarım bırakabileceklerini aktaran açıklama ile bilgilendirilmiş, ardından onayları alınarak yukarıda belirtilen veri toplama araçları doldurmaları istemiştir. Katılımcılar tüm sorulanı yanıtlamak için ortalama 15 dakika harcamışlardır. Online olarak toplanan verilerin incelenebilmesi amacıyla SPSS aracilığılla T Testi, Pearson Momentler Korelasyon Katsayısı, Çoklu Regresyon analizleri yapılmışıtır. 
Tablo 1. Katllmmclara Ait Verilerin Betimsel Analizlerine Ait Tablo

\begin{tabular}{|c|c|c|c|}
\hline Boyut & Grup & $n$ & $\%$ \\
\hline \multirow{2}{*}{ Cinsiyet } & Kadin & 226 & 55 \\
\hline & Erkek & 185 & 45 \\
\hline \multirow{2}{*}{ Medeni Durum } & Evli & 169 & 41,1 \\
\hline & Bekar & 242 & 58,9 \\
\hline \multirow{5}{*}{ Eğitim Durumu } & İlkokul & 6 & 1,5 \\
\hline & Ortaokul & 3 &, 7 \\
\hline & Lise & 79 & 19,2 \\
\hline & Lisans & 228 & 55,5 \\
\hline & Lisans Üstü & 95 & 23,1 \\
\hline \multirow{4}{*}{ Gelir Düzeyi } & 2200 TL ve alt1 & 140 & 34,1 \\
\hline & $2300-4500$ & 93 & 22,6 \\
\hline & $4500-6700$ & 86 & 20,9 \\
\hline & 6700 TL ve üstü & 92 & 22,4 \\
\hline \multirow{2}{*}{ Yüksek risk grubunda mısınız? } & Evet & 82 & 20,0 \\
\hline & Hayır & 329 & 80,0 \\
\hline \multirow{2}{*}{$\begin{array}{l}\text { Yaşadığınız evde (sizin dışınızda) yüksek risk grubunda } \\
\text { bulunan bir birey var mı? }\end{array}$} & Evet, var & 165 & 40,1 \\
\hline & Hayır, yok & 246 & 59,9 \\
\hline \multirow{5}{*}{$\begin{array}{l}\text { Koronavirüs'e karşı önerilen başlıca tedbirlere (el hijyeni, } \\
\text { sosyal mesafe, maske kullanımı) uyuyor musunuz? }\end{array}$} & Uymuyorum & 0 & 0 \\
\hline & Kismen Uyuyorum & 5 & 1,2 \\
\hline & Ne Uyuyorum Ne Uymuyorum & 19 & 4,6 \\
\hline & Genellikle Uyuyorum & 148 & 36,0 \\
\hline & Tamamen uyuyorum & 239 & 58,2 \\
\hline \multirow{3}{*}{$\begin{array}{l}\text { Ülkemizde ilk vakanın görüldüğü Mart ayına göre aldığınız } \\
\text { tedbirlerde bir değişim oldu mu? }\end{array}$} & Daha az tedbir alıyorum. & 118 & 42,6 \\
\hline & Aldığım tedbirlerde değişim olmadı. & 28,7 & 118 \\
\hline & Daha çok tedbir alıyorum. & 175 & 28,7 \\
\hline \multirow{5}{*}{$\begin{array}{l}\text { Koronavirüs nedeniyle hastanede tedavi görebileceğinizi } \\
\text { düşünüyor musunuz? }\end{array}$} & Asla & 46 & 11,2 \\
\hline & Nadiren & 96 & 23,4 \\
\hline & Ara sira & 159 & 38,7 \\
\hline & Çoğu Zaman & 65 & 15,8 \\
\hline & Her Zaman & 45 & 10,9 \\
\hline \multirow{5}{*}{ Salgının ne zaman sona ereceğini düşünüyorsunuz? } & 6 ay içerisinde & 26 & 6,3 \\
\hline & 6 ay-1 yıl içerisinde & 88 & 21,4 \\
\hline & 1-2 yil içerinde & 186 & 45,3 \\
\hline & 2 yildan daha uzun bir süre içerisinde & 69 & 16,8 \\
\hline & Hiçbir zaman sona ermeyecek & 42 & 10,2 \\
\hline \multirow{2}{*}{$\begin{array}{l}\text { Yakın çevrenizden Koronavirüs nedeniyle hastanede tedavi } \\
\text { gören bir yakınınız oldu mu? }\end{array}$} & Evet & 242 & 58,9 \\
\hline & Hayır & 169 & 41,1 \\
\hline \multirow{2}{*}{$\begin{array}{l}\text { Koronavirüs nedeniyle tedavi görmüş bireylerin hastalığa ve } \\
\text { tedavi sürecine ilişskin yaşantılarını hiç dinlediniz veya izlediniz } \\
\text { mi? }\end{array}$} & Evet & 337 & 82 \\
\hline & Hayır & 74 & 18 \\
\hline \multirow{2}{*}{$\begin{array}{l}\text { Kitle iletissim araçlarından açıklanan vaka sayılarını düzenli } \\
\text { olarak takip ettiniz mi? }\end{array}$} & Evet & 334 & 81,3 \\
\hline & Hayır & 77 & 18,7 \\
\hline \multirow{2}{*}{$\begin{array}{l}\text { Kitle iletişim araçlarından doktorların açıklamalarını düzenli } \\
\text { olarak takip ettiniz mi? }\end{array}$} & Evet & 296 & 72,0 \\
\hline & Hayır & 115 & 28,0 \\
\hline
\end{tabular}

Araştırmaya katılan bireylerden kadın katılımcılar 226 kişiyle grubun \%55'ini, erkek katıllımclar ise 185 kişiyle grubun \%45'ini oluşturmaktadır. Katılımcıların medeni durumlarına bakıldığında evli olduğunu belirten katıllımciların sayıs1 169 (\%41,1), bekâr olduğunu belirtenlerin sayısı 242 (58,9) olarak belirlenmiştir. Katılımcılardan 258 'i $(\% 62,8)$ çocuk sahibi olmadığını, 38’i $(\% 9,2)$ tek çocuk sahibi olduğunu, 91’i (\%22,1) 2 çocuk sahibi olduğunu, 18’i (\%4,4) 3 çocuk sahibi olduğunu ve 6’s1 $(\% 1,5)$ ise 4 çocuk sahibi olduğunu belirtiştir. Araştırmaya katılan katılımcılardan İlkokul Mezunu olduğunu belirten 6 kişi (\%1,5), Ortaokul Mezunu olduğunu belirten 3 kişi $(\%, 7)$, Lise Mezunu olduğunu belirten 79 kişi (\%19,2), Üniversite Mezunu olduğunu belirten 228 kişi $(\% 55,5)$ ve Lisansüstü Mezunu olduğunu belirten 95 kişi $(\% 23,1)$ bulunmaktadır. Katıllımclar gelir düzeylerine göre gruplandığında 2200 TL ve altında bulunan 140 katılımc1 (\%34,1), 2300 ve 4500 TL aralığında bulunan 93 katılımc1 (\%22,6), 4500 ve 6700 TL aralığında bulunan 86 katılımc1 $(\% 20,9)$ ve 6700 TL ve Üstü gelir düzeyine sahip 92 katıllımc1 $(\% 22,4)$ bulunmaktadır. Aktif olarak ev dışında çalışma durumlarına göre incelendiğinde katılımcıların 184'ü $(\% 44,8)$ aktif olarak ev dışında çalıştığını, 227'si ise $(\% 55,2)$ aktif olarak ev dışında çalısmadığını belirtmiştir.

Koronavirüs için risk grubunda bulunma durumlarına bakıldığı zaman 82 katıllımc1 (\%20) risk grubunda bulunduğunu, 329 katılımcı (\%80) ise risk grubunda olmadı̆̆ını belirtmiştir. Bunun yanında 


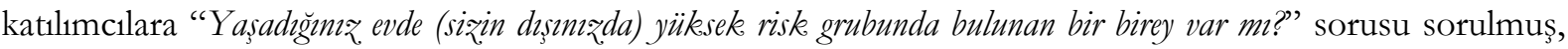
katılımciların 165'i (\%40,1) "Evet", 246'sı (\%59,9) ise bu soruya "Hayır" yanıtını vermiştir. Alınan tedbirlerin ne düzeyde olduğunun anlaşılması için katılımcılara "Koronavirüs'e karşı önerilen başlca tedbirlere (el bijyeni, sosyal mesafe ve maske kullanmi) uyuyor musunur?" diye sorulmuş, katılımciların 239 'u (\%58,2) tedbirlere tamamen uyduğunu, 148’i (\%36) genellikle uyduğunu, 19’u $(\% 4,6)$ ne uyduğunu ne uymadığını, 5’i $(\% 1,2)$ ise tedbirlere kısmen uyduğunu belirtmiştir. Katılımcılardan Ülkemizde ilk vakanın görüldüğu Mart ayından bu yana aldığı tedbirlerde bir değişim olup olmadığı sorusu yöneltilmiş 118 katıllımc1 yani grubun \%28,7'si sürecin başına göre daha az tedbir aldığını, 175 katılımcı yani grubun \%42,6'sı aldığı tedbirlerde bir değişim olmadığını ve 118 katılımc1 yani grubun \%28,7'si de sürecin başına göre daha çok tedbir aldığını belirtmiştir.

Kat1lımc1lara "Koronavirüs nedeniyle bastanede tedavi görebileceğinizi düş̈̈nüyor musunuz?" sorusu yöneltildiğinde katılımcıların 46's1 (\%11,2) “Asla Düşünmüyorum”, 96 's1 $(\% 23,4)$ "Nadiren Düşünüyorum”, 159’u (\%38,7) “Ara sıra Düşünüyorum”, 65’i (\%15,8) “Çoğu Zaman Düşünüyorum” ve 45’i (\%10,9) "Her Zaman Düşünüyorum" yanıtını vermiştir. Katıllımcılara "Salgzmn ne zaman sona ereceğini düş̈̈n̈̈yorsunuz??" sorusu yöneltildiğinde 26 katıllımc1 $(\% 6,3)$ önümüzdeki alt ay içerisinde, 88 katılımc1 (\%) önümüzdeki 6 ay ile 1 yıl arasında, 186 kattlımcı (\%45,3) önümüzdeki 1 yil ile 2 yıl arasında biteceğini düşündüklerini belirtmişlerdir. 69 katılımcı $(\% 16,8)$ salgının önümüzdeki 2 yıl içerisinde sonlanmayacağını ve daha uzun süreceğini, 42 katılımcı $(\% 10,2)$ ise salgının hiçbir zaman bitmeyeceğini düşündüklerini belirtmişlerdir. Katılımcılara salgının başladığı döneme göre Koronavirüs'e dair bilgi düzeylerinde önemli derecede bir artış olup olmadığı sorusu sorulduğunda ise 361 katılımcı $(\% 87,8)$ bilgi düzeylerinin arttığını, 50 katılımc1 $(\% 12,2)$ ise bilgi düzeylerinde bir artış olmadığını belirtmişlerdir. Katılımcılara yakın çevrelerinde Koronavirüs nedeniyle hastanede tedavi gören bir yakınları (aile bireyi, akraba veya arkadaş gibi) olup olmadığı sorulmuş, 242 katılımcının $(\% 58,9)$ "Evet" yanıtını vermiş olduğu, 169 katılımcının $(\% 41,1)$ "Hayır" yanıtını vermiş olduğu görülmüştür.

Katıllımclara "Koronavirüs nedeniyle tedavi görmüs bireylerin hastalĭga ve tedavi sürecine ilişkin yasantlarm dinlediniz veya izlediniz mi?" sorusu yöneltildiğinde 337 katılımc1 yani grubun \%82'si "Evet”, 74 katıllımc1 yani grubun \%18'i "Hayır" yanıtını vermiştir. Katıllmcılara "Koronavirüs salgim sirasinda televišyon ve diğer kitle iletisim araclarndan açılanan vaka sayllarm düzenli olarak takip ettiniそ, mi?" sorusu yöneltildiğinde ise 334 katılımc1 yani grubun \%81,3'ünün vaka sayılarını düzenli olarak takip ettiği, 77 katılımc1 yani grubun $\% 18,7$ ’sinin vaka sayılarını düzenli olarak takip etmediklerini belirttikleri görülmüştür. Son olarak katılımcilara "Koronavirüs salgim sirasinda televisyon ve diğer kitle iletişim araçlarndan doktorlarn açılamalarm dïzenli olarak takip ettini mi?" sorusu yöneltilmiş ve katılımcıların 296'sının (\%72) bu soruya "Evet", 115 'inin (\%28) ise "Haylr" yanıtı verdiği görülmüștür.

Tablo 2. Araștırmaya Katılan Bireylerin Cinsiyetlerine Göre Koronavirüs Korkularm Gösteren Tablo

\begin{tabular}{cccccccc}
\hline Değişkenler & Cinsiyet & $\boldsymbol{n}$ & $\boldsymbol{A O}$ & $\boldsymbol{S S}$ & $\boldsymbol{t}$ & $\boldsymbol{S d}$ & $\boldsymbol{p}$ \\
\hline \multirow{2}{*}{ KKÖ } & Kadın & 226 & $18,4616,20$ & 6.18 & 3.61 & 6.2 & .000 \\
& Erkek & 185 & & 6.36 & & & \\
\hline
\end{tabular}

Katıllımcıların Koronavirüs Korkusu Ölçeği’nden aldıkları puanlar cinsiyet değişkeni açısından incelendiğinde katılan 226 kadın katılımcının KKÖ'den aldıkları puanların ortalaması 18,4, standart sapma değeri ise 6,1 olarak bulgulanmıştır. 185 erkek katılımcının KKÖ'den aldığ1 puanların ortalamasına bakıldığında 16,2, standart sapma değeri ise 6,3 olarak hesaplanmıştır. Katılımcıların Koronavirüs Korkusu Ölçeği’nden aldıkları puanların cinsiyetlerine göre farklılaştı̆̆ı görülmektedir. Bu veriler 1şı̆̆ında kadın katılımcıların Covid-19 korku düzeylerinin erkeklerden yüksek olduğunu söylemek mümkündür.

Tablo 3. Covid-19 Nedeniyle Hastanede Tedavi Gören Yakına Sahip Olmaya Göre KKÖ Puanlarm ve Hastanede Tedavi Görebileceklerini Düssünme Sıklğını Gösteren Tablo

\begin{tabular}{|c|c|c|c|c|c|c|c|}
\hline Değişkenler & $\begin{array}{c}\text { Tedavi gören yakına } \\
\text { sahip olma }\end{array}$ & $n$ & $A O$ & $S$ & $t$ & $S d$ & $p$ \\
\hline KKÖ & $\begin{array}{l}\text { Evet } \\
\text { Hayır }\end{array}$ & $\begin{array}{l}242 \\
169\end{array}$ & $\begin{array}{l}18,02 \\
16,62\end{array}$ & $\begin{array}{l}6.34 \\
6.31\end{array}$ & 2.20 & .63 & .028 \\
\hline $\begin{array}{l}\text { Koronavirüs Nedeniyle } \\
\text { Hastanede Tedavi } \\
\text { Görebileceğini Düşünme } \\
\text { Sıklı̆̆1 }\end{array}$ & $\begin{array}{l}\text { Evet } \\
\text { Hayır }\end{array}$ & $\begin{array}{l}242 \\
169\end{array}$ & $\begin{array}{l}3.02 \\
2.77\end{array}$ & $\begin{array}{l}1,12 \\
1,11\end{array}$ & 2.18 & .11 & .030 \\
\hline
\end{tabular}


Tablo 3 incelendiğinde yapılan $\mathrm{T}$ Testi sonucunda bireylerin yakın çevrelerinde Koronavirüs nedeniyle hastanede tedavi gören bir yakınlarının bulunup bulunmaması durumuna göre Koronavirüs korkularının ve Koronavirüs nedeniyle hastanede tedavi görebileceklerini düşünme düzeylerinin farklılaştığı anlaşılmaktadır $(\phi<.05)$. Tedavi gören yakına sahip bireylerin Covid-19 korkularının ve kendilerinin de Covid-19 nedeniyle hastanede tedavi görebileceğini düşünme sıklıklarının daha yüksek olduğu anlaşılmaktadır. Bunun yanında bireylerin yakın çevrelerinde Koronavirüs nedeniyle hastanede tedavi gören bir yakınlarının (aile bireyi, akraba veya arkadaş gibi) bulunup bulunmamasıyla yaşam yönelimleri, bilişsel-davranışsal kaçınma düzeyleri ve Koronavirüs'e karşı önerilen başlıca tedbirlere uyma düzeyleri arasında anlamlı bir ilişkiye rastlanılmamıstır ( $p>.05)$.

Tablo 4. Bireylerin Tedavi Sürecine Tanı Olma Durumlarna Göre Tedbirlere Uyum Düzeylerini Gösteren Tablo

\begin{tabular}{clcccccc}
\hline Değiskenler & Tedavi sürecine tanık & $\boldsymbol{n}$ & $\boldsymbol{A O}$ & $\boldsymbol{S}$ & $\boldsymbol{t}$ & $\boldsymbol{s} \boldsymbol{d}$ & $\boldsymbol{p}$ \\
\hline \multirow{2}{*}{ Tedbirlere Uyum } & Evet & 337 & 4.57 & .59 & 4.2 & 0.8 & .000 \\
& Hayir & 74 & 4.22 & .76 & & & \\
\hline
\end{tabular}

Yapılan T Testi sonucunda Koronavirüs nedeniyle tedavi görmüş bireylerin hastalı̆ga ve tedavi sürecine ilişkin yaşantılarını izleme/dinleme durumlarına göre Koronavirüs'e karşı önerilen başlıca tedbirlere (el hijyeni, sosyal mesafe, maske) uyma düzeylerinin anlamlı şekilde farklılaştığ bulunmuştur $(p<.05)$. Dolayısıyla tedavi sürecine tanık olan katılımciların tanık olmayanlara göre tedbirlere uyum düzeyleri daha yüksektir. Öte yandan bireylerin Koronavirüs nedeniyle tedavi görmüş kişilerin hastalığa ve tedavi sürecine ilişkin yaşantıları dinleme/izleme durumları ile yaşam yönelimleri, Koronavirüs korkuları, bilişsel davranışsal kaçınma düzeyleri ve Koronavirüs nedeniyle hastanede tedavi görebileceklerini düşünme düzeyleri arasında anlamlı bir ilişkiye rastlanılmamıştır ( $p>0.05)$.

Tablo 5. Doktorlarn Açılamalarm Düzenli Takip Edip Etmeme Durumuna Göre KKÖ Puanlarm, Tedbirlere

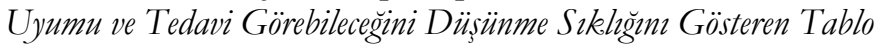

\begin{tabular}{|c|c|c|c|c|c|c|c|}
\hline Değişkenler & $\begin{array}{c}\text { Doktorların } \\
\text { açıklamalarını } \\
\text { düzenli takip etme }\end{array}$ & $n$ & $A O$ & $S$ & $t$ & $S d$ & $p$ \\
\hline KKÖ & $\begin{array}{l}\text { Evet, ettim } \\
\text { Hayır }\end{array}$ & $\begin{array}{l}296 \\
115\end{array}$ & $\begin{array}{l}18,21 \\
15,45\end{array}$ & $\begin{array}{l}6.45 \\
5.66\end{array}$ & 4.03 & .68 & .000 \\
\hline Tedbirlere Uyum & $\begin{array}{l}\text { Evet, ettim } \\
\text { Hayır }\end{array}$ & $\begin{array}{l}296 \\
115\end{array}$ & $\begin{array}{l}4.59 \\
4.30\end{array}$ & $\begin{array}{l}.58 \\
.73\end{array}$ & 3.72 & .069 & .000 \\
\hline $\begin{array}{l}\text { Tedavi görebileceğini } \\
\text { düşünme sıklığ1 }\end{array}$ & $\begin{array}{l}\text { Evet, ettim } \\
\text { Haylr }\end{array}$ & $\begin{array}{l}296 \\
115\end{array}$ & $\begin{array}{l}3.03 \\
2.63\end{array}$ & $\begin{array}{l}1.08 \\
1,18\end{array}$ & 3.10 & .12 & .002 \\
\hline
\end{tabular}

Yapılan T Testi sonucunda Koronavirüs salgını sırasında televizyon ve diğer kitle iletişim araçlarından doktorların açıklamalarını düzenli takip edip etmeme durumuna göre Koronavirüs korkusu, tedbirlere uyma düzeyi ve hastanede tedavi görebileceğini düşünme düzeyinin anlamlı şekilde farklılaşttğ1 görülmüştür $(p<.05)$. Vaka sayılarını düzenli olarak takip eden katılımcıların etmeyenlere kıyasla KKÖ puanlarının daha yüksek olduğu, tedavi görebileceklerini daha sık düşündükleri ve tedbirlere uyum düzeyinin daha yüksek olduğu bulgulanmıştır. Bunun yanında bireylerin salgın sırasında doktorların açıklamalarını düzenli takip edip etmemeleri ile yaşam yönelimleri ve bilişsel-davranışsal kaçınma düzeyleri arasında anlamlı bir ilişki bulunamamıştır ( $p>.05)$.

Tablo 6. Aģılanan Vaka Sayılarm Düzenli Takip Etme Durumuna Göre KKÖ Puanlarm, Tedbirlere Uyum Düzeyini ve Covid-19 Nedeniyle Hastanede Tedavi Görebileceğini Düș̈̈nme Sıkliğmn Gösteren Tablo

\begin{tabular}{|c|c|c|c|c|c|c|c|}
\hline Değişkenler & $\begin{array}{c}\text { Vaka sayısını düzenli } \\
\text { takip etme }\end{array}$ & $n$ & $A O$ & $S$ & $t$ & $S d$ & $p$ \\
\hline \multirow{2}{*}{$\mathrm{KKÖ}$} & Evet, ettim & 334 & 17,98 & 6.31 & 3.73 & .77 & .000 \\
\hline & Hayır & 77 & 15,10 & 6.05 & & & \\
\hline \multirow{2}{*}{ Tedbirlere Uyum } & Evet, ettim & 334 & 4.56 & .58 & 3.85 & .030 & .000 \\
\hline & Hayır & 77 & 4.25 & .83 & & & \\
\hline \multirow{2}{*}{$\begin{array}{l}\text { Tedavi görebileceğini } \\
\text { düşünme sıklığ1 }\end{array}$} & Evet, ettim & 334 & 2.99 & 1.10 & 2.57 & .14 & .010 \\
\hline & Hayır & 77 & 2.62 & 1,20 & & & \\
\hline
\end{tabular}

Yapılan T Testi sonucunda Koronavirüs salgını sırasında açıklanan vaka sayılarını takip edip etmeme durumuna göre Koronavirüs korkusu, tedbirlere uyma düzeyi ve hastanede tedavi görebileceğini düşünme düzeyinin anlamlı şekilde farklılaştığı görülmüştür $(p<.05)$. Doktorların açıklamalarını düzenli olarak takip 
eden katılımcıların etmeyenlere göre KKÖ puanlarının daha yüksek olduğu, tedavi görebileceklerini daha sık düşündükleri ve tedbirlere uyum düzeyinin daha yüksek olduğu bulgulanmıştır. Öte yandan vaka sayılarını düzenli takip edenler ve etmeyenler arasında yaşam yönelimi ve bilişsel davranışsal kaçınma düzeyleri açısından anlamlı bir farklıı̆̆a rastlanılmamıştır $(p>, 05)$.

Tablo 7. Katılimalara ait BDKÖ, YYT-R ve KKÖ Puanlan Arasindaki İliskileri Gösteren Tablo

\begin{tabular}{|c|c|c|c|c|c|c|c|c|}
\hline Değişkenler & Min-Max & $A O$ & $S$ & Skewness & Kurtosis & 1 & 2 & 3 \\
\hline $1 \mathrm{BDKÖ}$ & $29-139$ & 64.3 & 20.3 & .717 & .575 & & $-.373^{*}$ & $.315^{*}$ \\
\hline 2 YYT-R & $6-30$ & 20.8 & 3.9 & -.314 & .513 & $-.373 *$ & & $-.238^{*}$ \\
\hline $3 \mathrm{KKÖ}$ & $7-35$ & 17.4 & 6.3 & .486 & -.388 & $.315^{*}$ & $-.238^{*}$ & \\
\hline Yaș & $18-72$ & 31.9 & 11.7 & 1.058 & .246 & & $.144^{*}$ & \\
\hline Tedbirlere Uyum & $2-5$ & 4.5 & .645 & -1.24 & 1.56 & & & $.143^{*}$ \\
\hline
\end{tabular}

Araştırma kapsamında incelenen değişkenlerin arasındaki ilişkilerin belirlenebilmesi için Pearson Momentler Çarpımı Korelasyon Katsayısından yararlanılmıştır. Araştırmaya konu değisskenlerin aralarında istatistiksel olarak anlamlı bir ilişki olup olmadığını anlamak için yapılan analizlerde:

Araştırmaya katılan bireylerin yaşları ve Yaşam Yönelimi Ölçeği’nden Aldıkları toplam puanlar arasındaki ilişkiye bakıldığı zaman istatistiksel olarak anlamlı, pozitif yönlü ve düşük düzey bir ilişki olduğu görülmüştür $(\mathrm{r}=$,144). Bunun anlamı araştırmaya katılan bireylerin yaşları arttıkça iyimserlik düzeylerinin de arttığıdır. Katılımcıların Koronavirüs'e karşı önerilen başlıca tedbirlere (el hijyeni, sosyal mesafe, maske kullanımı) uyma düzeyleri ve Koronavirüs Korkusu Ölçeği’nden aldıkları toplam puanlar arasındaki ilişki incelendiğinde, istatistiksel olarak anlaml, pozitif yönlü ve düşük düzey bir ilişki olduğu görülmüştür ( $\mathrm{r}=$ ,143). Bu veriden yola çıarak katılımcılarnn tedbirlere uyma düzeyi arttıkça Koronavirüs korkusu düzeylerinin de arttığını söylemek mümkündür. Katılımcıların Yaşam Yönelimi Ölçeği’nden aldıkları puanlar ile Bilişsel Davranışsal Kaçınma Ölçeği’nden aldıkları toplam puanlar arasındaki ilişkiye bakıldığında, istatistiksel olarak anlamlı, negatif yönlü ve orta düzeyde bir ilişki olduğu bulgulanmıştır ( $\mathrm{r}=$ ,373). Yani katılımcıların iyimserlik düzeyi azaldıkça bilişsel-davranışsal kaçınma düzeylerinin artmaktadır. Yaşam yönelimi ve Koronavirüs korkusu arasındaki ilişkiye bakıldığında, katılımcıların YYÖ’den aldıkları puanlar ve KKÖ'den aldıkları puanlar arasında, istatistiksel olarak anlamlı, negatif yönde ve düşük düzeyde bir ilişsinin olduğu görülmüştür $(\mathrm{r}=-, 238)$. Dolayısıyla katllımcıların karamsarlık düzeyi arttıkça Koronavirüs korkusu düzeylerinin azalmaktadır. Bilişsel davranışsal kaçınma ve Koronavirüs korkusu arasındaki ilişkiye bakıldığında, katılımcıların BDKÖ'den aldıkları puanlar ve KKÖ'den aldıkları puanlar arasında, istatistiksel olarak anlamlı, pozitif yönlü ve orta düzey bir ilişki olduğu bulgulanmıştır $(r=, 315)$. Bunun anlamı katılımcıların bilişsel ve davranışsal kaçınma düzeyleri arttıkça Koronavirüs korkusu düzeylerinin de arttığıdır.

Tablo 8. Yașam Yönelimi ve Bilisssel Davranıssal Kaçımann Covid-19 Korkusunu Yordayıc Gücüne Ait Verileri İceren Tablo

\begin{tabular}{|c|c|c|c|c|c|c|c|}
\hline Model & $\beta$ & $\begin{array}{c}\text { Standart } \\
\text { Hata }\end{array}$ & Beta & $t$ & $p$ & Íkili $r$ & Kismi \\
\hline (Sabit) & 16.82 & 2.28 & & 7.378 & $.000^{*}$ & & \\
\hline YYT-R & -.225 & .081 & -.140 & $\begin{array}{l}-2.79 \\
\end{array}$ & $.005^{*}$ & -.137 & -130 \\
\hline BDKÖ & .085 & .016 & .263 & 5.24 & $.000^{*}$ & .251 & .244 \\
\hline
\end{tabular}

Varsayımlarının karşılanması sonucunda yapılan çoklu regresyon analizi sonucunda, yaşam yönelimi ve bilişsel davranışsal kaçınma değişkenlerinin kombinasyonun yaşam doyumunu anlamlı şekilde yordadığ1 bulgulanmıştır [F (2, 408), $\mathrm{p}<.001$, adj. $\left.\mathrm{R}^{2}=.11\right]$. Katılımcıların bilişsel davranışsal kaçınmaları ile Koronavirüs korkuları arasında pozitif yönlü yordayıcı bir ilişki söz konusudur $\beta=.26, \mathrm{p}<.001, \% 95 \mathrm{CI}$ $[.051, .113], \mathrm{pr}^{2}=063, \mathrm{sr}^{2}=.6$. Yani katılımcıların Koronavirüs korkularındaki değişimlerin \%6'sı bilişsel davranışsal kaçınmalarıyla açıklanabilmektedir. Ayrıca yaşam yönelimi ile Koronavirüs Korkusu arasında anlamlı düzeyde negatitif yönlü yordayıcı bir ilişki bulgulanmıştır $\beta=-.14, \mathrm{p}=005, \% 95$ CI [-.384, -.067], $\mathrm{pr}^{2}=.018, \mathrm{sr}^{2}=.2$. Sonuç olarak bireylerin yaşam yönelimlerinin ve bilişsel davranışsal kaçınmalarının, Koronavirüs korkularını anlamlı düzeyde yordadığı ve bireylerin Koronavirüs korkularındaki değişimlerin \%11'ni açıkladığı bulunmuştur. 


\section{Tartışma, Sonuç ve Öneriler}

Kadınların erkeklere göre çok daha sık kaygı ve korku bozuklukları yaşadıkları bilinmektedir (Carter, Wittchen, Pfister ve Kessler, 2001, s. 86; Wittchen, 2002, s. 163). Kadınların Koronavirüs korkularının erkeklerden daha yüksek olduğu bulgusu Haktanır ve arkadașlarının (2020, s. 3) çalıșmasının bulgularıyla örtüşmektedir. Öte yandan Ahorsu ve arkadaşlarının (2020, s. 6) çalışmasında ise Covid-19 korkusu düzeyinde cinsiyetlere göre anlamlı bir farklılık gözlemlenmemiştir. T.C. Sağlık Bakanlığı'nın (2020, s. 12) 50 yaş üzerinde bulunan bireylerin Covid-19 için daha genç bireylere göre daha yüksek risk taşıdı̆ı̆nı ifade etmesine karşın diğer çalışmalarla (Ahorsu vd., 2020, s. 4; Haktanır vd., 2020, s. 6) benzer şekilde Koronavirüs korkusu düzeyi ile yaş arasında anlamlı bir ilişkiye rastlanılmamıştır. Buna ek olarak yüksek risk grubunda bulunduğunu belirten bireyler ve yüksek risk grubunda bulunmadığını belirten bireyler arasında Covid-19 korkusu düzeyi bakımından anlamlı bir farka rastlanılmamıştır. Yaşam yönelimi yani iyimserlik ve kötümserlik ile yaş arasındaki ilişki incelendiğinde düşük düzeyde de olsa pozitif yönlü anlamlı bir ilişsi görülmektedir. Sivri (2019, s. 68) de yaşam yönelimi ile yaş grupları arasında anlamlı farklılar olduğunu bildirmektedir. Sivri (2019, s. 68) 41 yaş ve üzerindeki bireylerin iyimserliğinin genç yetişkinlerden daha yüksek olduğunu bildirmektedir.

Koronavirüs nedeniyle hastanede tedavi gören yakına sahip olan bireylerin Koronavirüs korkularının ve kendilerinin de hastanede tedavi görebileceğini düşünme sıklı̆ıının çevresinde hastanede tedavi gören birey bulunmayanlara göre daha yüksek olduğu görülmektedir. Bu durumun olası nedenlerinden birisinin Covid-19 olma riskinin farkında olunması ve dolayısıyla yakından tanıdıkları bir bireyin yaşadıklarının kendilerinin de yaşamasının olası olduğunu düşünmeleridir. Zira bireylerin ölümcül hastalıkların ve çeşitli felaketlerin kendi başlarına gelme olasılıklarını gerçekten düşük görebildikleri bilinmektedir (Mansfield, 2007, s. 8). Ancak bireyin yakın çevresinden birisi bu tür istenmeyen yaşantılara maruz kaldığında hastalıkların veya felaketlerin yaşanma olasılıkları daha gerçekçi olarak tahmin edilebilmekte hatta gerçeğin de üstünde görülebilmektedir. Örneğin Kabakaş (2018, s. 16-21) kanser hastası yakınlarının kansere yakalanma korkularının, ölüm korkularının ve sağlık anksiyetesi düzeylerinin kanser hastası yakını olmayan bireylere nazaran daha yüksek olduğunu ifade etmektedir. Korku ve sağlıkla ilgili davranışlar arasındaki ilişkinin oldukça karmaşık olduğu bilinmektedir. Korku öğesi (fear appeals) kavramı aradaki bu karmaşık ilişkiye ışık tutabilecek olası açılamalardan birisidir (Pakpour ve Griffiths, 2020, s. 3). "Fear Appeals" yani korku öğesi kavramının korku çekiciliği, korku çağrısı veya korku güdüsü olarak da literatürde kullanıldığ1 bilinmektedir (Çobaner, 2013, s. 212). Virüs kapma ile ilgili gerçekçi risk algısının ve korkunun önleyici davranışları artırabileceği birçok çalışmada gösterilmiştir (Harper vd. 2020, s. 7; Raude vd., 2020; Wise vd., 2020, s. 8). Bizim çalışmamızda da Koronavirüs korkusunun arttıkça tedbirlere uyumun arttığ1 düşük düzeyde de olsa görülmüştür. Öte yandan Koronavirüs korkusunun yüksek olmasının yol açabileceği tehditler (Goyal vd., 2020, s. 1; Ahorsu vd., 2020, s. 2; Mamun ve Griffiths, 2020, s. 1) unutulmamalıdır.

Korku öğesi, uyarılara uyulmaması halinde bireyin başına gelebileceklere dikkat çekilen mesaj türüdür ve sağlıkla ilgili sigara içmek, kendi kendine meme muayenesi, uygun ilaç kullanımı gibi konulara dair bilgilendirmelerde sıklıkla kullanıldığı bilinmektedir (Tannenbaum vd., 2014, s.16; Williams, 2012). Zira bireyler korku öğesiyle tehdidin farkına varıp buna yönelik önlemler alabilmekte, davranış değişlikleri gösterebilmektedir (Rogers, 1985). Covid-19 nedeniyle hastanede tedavi gören bireylerin hastalık ve tedavi sürecine dair yaşantılarının izlenmesi ya da dinlenmesi yani tedavi sürecine tanık olunması halinde tanık olmayan bireylere göre tedbirlere daha çok uyulması bulgusunun korku öğesi kavramıyla ilişkili olabileceği düşünülmektedir. Şöyle ki sigara paketleri üzerindeki bilgilendirici mesajların ve sigaranın etkilerini gösteren görsellerin sigara kullanan veya kullanmayan bireylerde etkili olduğu bilinmektedir (Mazlum ve Mazlum, 2014, s. 12). Hatta sigara içen bireyler bu görüntülerin kendilerinde bir etki uyandırmadığını ifade etseler bile bu bireylerin beyin aktiviteleri incelendiğinde etkilendikleri bulgulanmıştır (Sadegil, 2016, s. 141). Dolayısıyla sigara içen bireylerde görsellerin görülmesiyle oluşan etki gibi hastanede Covid-19 tedavisi alan birisinin yaşantılarına tanık olunması da tedbir davranışlarına yöneltebilmesi mümkündür. Fakat tedavi sürecine tanık olanların tanık olmayan bireylere göre tedbirlere daha çok uyması bulgusunun korku öğesi kavramıyla kesin olarak ilişkili olup olmadığı bilinmemektedir. Söz konusu ilişkinin nedenselliğinin bu araştırmanın kapsamı dışında kalması nedeniyle tam olarak bir yargıya varılması oldukça güçtür.

Pandemi sürecinde doktorların açıklamalarını düzenli takip eden katılımcıların takip etmeyenlere kıyasla Covid-19 korkularının, tedbirlere uyumlarının ve tedavi görebileceğini düşünme sıklığının daha yüksek olduğu tespit edilmiştir. Buna paralel olarak vaka sayılarını düzenli takip edenlerin etmeyenlere kıyasla Covid-19 korkularının, tedbirlere uyumlarının ve tedavi görebileceğini düşünme sıklığının daha 
yüksek olduğu bulgulanmıştır. Dünya Sağlık Örgütü (2020b, s. 3) halkın uzman hekimlerce ve devletlerin ilgili kanallarıyla bilgilendirilmesinin salgınla mücadelede, tedbirlerin alınmasında önemli bir rol oynadığını ifade etmektedir.

Kötümser bireylerin iyimserlere göre daha çok uyumsuz başa çıkma yollarına başvurdukları bilinmektedir. Uyumsuz başa çıma stratejilerinden olan kaçınma ile iyimserlik-kötümserlik arasındaki ilişki incelendiğinde; kötümser bireylerin rahatsılılk veren durumlarda daha çok kaçınmaya başvurduğu görülmektedir (Aspinwall ve Taylor, 1992, s. 995; Carver vd., 1993, s. 380; Nes ve Segerstrom, 2006, s. 244). Bu bilgilerle uyumlu olarak bizim çalışmamızda da bilişsel davranışsal kaçınma ile iyimserlik arasında negatif yönlü anlamlı bir ilişki bulgulanmıştır.

Andersson (1996, s. 722) iyimser bireylerin stres yaratan durumlarda daha az sikıntı/rahatsılik bildirdiğini ve iyimserlik ile olumsuz duygulanım arasında önemli düzeyde bir ilişki olduğunu ifade etmektedir. Ayrıca iyimserlerin, başa çıkma stratejilerini mevcut stresörlerin taleplerini karşılayacak şekilde ayarlayabildikleri bilinmektedir (Nes ve Segerstrom, 2006, s. 247). Yaşam yönelimi ile Koronavirüs korkusu arasında negatif yönlü ve düşük düzeyde ilisski tespit edilmiştir. Yani katılımcıların iyimserlik düzeyi arttıkça Koronavirüs korkusu düzeyi azalmaktadır. Ayrıca yaşam yöneliminin Koronavirüs kokusunun anlamlı bir yordayıcısı olduğu bulgulanmıstır. Bu bulgular iyimserlik düzeyi yüksek bireylerin; sağlığa iliş̧kin davranışlara karşı daha hassas olması (Geers vd., 2010, s. 132) ve koruyucu sağlık davranışlarının daha fazla olması (Ingledew ve Brunning, 1999, s. 200) verileriyle örtüşmektedir. Bu bulgular, Dolinski vd.'nin (2020, s. 6) öne sürdüğ̈ gerçekçi olmayan iyimserliğin tedbirlere yetirince uymamanın önemli bir nedeni olabileceği fikri ile çelişiyor gibi görünse de bu çalışmada iyimserliğin genel bir eğilim olarak ele alındığ ve gerçekçi olmayan iyimserliğin ölçümlenmediği göz önünde bulundurulmalıdır.

Bizim çalışmamızda da diğer salgınlarda (Goodwin vd., 2011, s. 90; Leppin ve Aro, 2009, s. 22; Wu vd., 2005, s. 41) ve Covid-19 salgınında yapılmış çalışmalarla (Shabahang, 2020, s. 91; Ganson vd., 2020, s. 3406) paralel olarak bilişsel davranışsal kaçınma ile Koronavirüs korkusu arasında pozitif yönlü ilişski saptanmıştır. Buna ek olarak bilişsel davranışsal kaçınmanın Koronavirüs korkusunu yordadağı çalısmamızda görülmüştür. Sonuç olarak bilişsel davranışsal kaçınma ve yaşam yöneliminin Koronavirüs korkusunu yordadağı ve Koronavirüs korkusu puanlarındaki değişimlerin \%11'ini açıkladığı bulgulanmıştır.

Koronavirüs nedeniyle bir yakınının tedavi gördügünü belirten katıllımcıların böyle bir yaşantı geçirmemiş katılımcilara göre daha fazla Covid-19 korkusu ve kendilerinin de tedavi görebileceklerini daha sık düşünmelerinden hareketle bireylere virüsün yayılma yollan, önerilen tedbirler ve mevcut tedavi yöntemleri hakkında doğru bilgilerin verilmesi önemlidir. Hastalığa yakınları vesilesiyle tanık olmuş bireylerin virüsten korkması ve kendilerinin de yakalanacaklarını düşünmeleri beklenen ve doğal bir durumdur. Ancak böyle durumlarda bireylerin olay hakkında gerçekçi düşünmeleri sekteye uğrayabilir ve korkuya odaklanıp uyumsuz baş etme yollarına başvurabilirler. Bu nedenle bireylerin virüsten korunmak için denediği yolların etkililiğini bilmesi önemlidir. Yine Covid-19 korkusunun artışyla önleyici davranışların artması beklenen bir sonuçtur. Ancak korkunun aşırı yoğun olduğu durumlarda bireylerin önerilen önlemlerin dışında çeşitli uyumsuz davranışlar da göstermelerine neden olabilir (Ahorsu, 2020, s. 2). Bu nedenle yayılma yolları ve öneriler hakkında gerçekçi bilgilerin verilebilmesi yine önem arz etmektedir. Ayrıca araştırmaya katılan 411 bireyin \%10,2'sinin salgının hiçbir zaman bitmeyeceğini düşünmesi de göz ardı edilmemelidir.

Araştırmanın bulgularına bakıldığında bireylerin iyimserlik düzeylerinin arttıkça Koronavirüs korkularının azalma gösterdiği görülmüştür. Ayrıca katılımcıların iyimserlik düzeyi azaldıkça bilişseldavranışsal kaçınma düzeyleri artmaktadır. Bireylere gerekli psikolojik yardım hizmetlerinin sağlanmasında alanda çalışan uzmanların bu çalışmada ortaya çıkarılan ilişkileri de göz önünde bulundurması faydalı olabilecektir. Bahsi geçen değişkenler arasındaki nedensellik ilişkilerine dair daha çok araştırmaya ihtiyaç duyulmaktadır. Buna ek olarak daha geniş katılımlı çalışmaların yapılmasının faydalı olabileceğini söylemek mümkündür.

\section{Etik Beyan}

"Yaşam Yöneliminin Bilișsel Davranıșsal Kaçnmann COVID-19 Korkusunu Yordayıc Gücünün Belirlenmesi ve Cessitli Değģskenlerle Olan İlişkilerinin İncelenmesi” başlıklı çalışmanın yazım sürecinde bilimsel kurallara, etik ve alıntı kurallarına uyulmuş; toplanan veriler üzerinde herhangi bir tahrifat yapılmamış ve bu çalışma herhangi başka bir akademik yayın ortamına değerlendirme için gönderilmemiştir. Gerekli olan etik kurul 
izinleri Necmettin Erbakan Üniversitesi Sosyal ve Beşeri Bilimler Bilimsel Araştırmalar Etik Kurulu'nun 18.12.2020 tarih ve 3 sayılı toplantısında 2020/131 nolu karar ile alınmıştır.

\section{Kaynakça}

Ahorsu, D. K., Lin, C., Imani, V., Saffari, M., Griffiths, M. D. ve Pakpour, A. H. (2020). The fear of COVID-19 scale: Development and initial validation. International Journal of Mental Health and Addiction.

Andersen, K. G., Rambaut, A., Lipkin, W. I., Holmes, E. C. ve Garry, R. F. (2020). The proximal origin of SARSCoV-2. Nature medicine, 26(4), 450-452.

Andersson, G. (1996). The benefits of optimism: A meta-analytic review of the Life Orientation Test. Personality and Individual Differences, 21(5), 719-725.

Arslan, G., Yıldırım, M., Tanhan, A., Buluş, M. ve Allen, K. A. (2020). Coronavirus stress, optimism-pessimism, psychological inflexibility, and psychological health: Psychometric properties of the Coronavirus Stress Measure. International Journal of Mental Health and Addiction, 1.

Aspinwall, L. G. ve Taylor, S. E. (1992). Modeling cognitive adaptation: A longitudinal investigation of the impact of individual differences and coping on college adjustment and performance. Journal of Personality and Social Psychology, 63(6), 989-1003.

Avşaroğlu, S. ve Koç, H. (2019). Yaşam Doyumu ile Sıkıntıyı Tolere Etme Arasındaki İlişkide İyimserliğin Aracı Etkisi. Turkish Psychological Counseling and Guidance Journal, 9(53).

Avşaroğlu, S. ve Okutan, H. (2018). Zihin engelli çocuğu olan ailelerin yaşam doyumları, iyimserlik ve psikolojik belirti düzeylerinin incelenmesi. Manas Sosyal Araștırmalar Dergisi, 7(1), 59-76.

Aydın, G. ve Tezer, E. (1991). İyimserlik, sağlık sorunları ve akademik başarı ilişkisi. Psikoloji Dergisi, 7(26), 2-9.

Banerjee, D. (2020). The COVID-19 outbreak: Crucial role the psychiatrists can play. Asian journal of psychiatry, 50, 102014.

Beck, A. T. ve Emery, G. (2019). Anksiyete Bozukluklar ve Fobiler: Bilişssel Bir Bakııs Açısı. (Çev. V. Öztürk). İstanbul: Litera Yayıncilık. (Orijinal yayın tarihi, 2005)

Brooks, S. K., Webster, R. K., Smith, L. E., Woodland, L., Wessely, S., Greenberg, N. ve Rubin, G. J. (2020). The psychological impact of quarantine and how to reduce it: rapid review of the evidence. The Lancet.

Burger, J. M. ve Burns, L. (1988). The illusion of unique invulnerability and the use of effective contraception. Personality and Social Psychology Bulletin, 14(2), 264-270.

Büyüköztürk, Ş., Çakmak, E. K., Akgün, Ö. E., Karadeniz, Ş. ve Demirel, F. (2016). Bilimsel Araştırma Yöntemleri (21. Bask1). Ankara: Pegem Akademi Yayınları

Carter, R. M., Wittchen, H-U., Pfister, H. ve Kessler, R. C. (2001). One Year Prevalence of Subthreshold and Threshold DSM-IV Generalized Anxiety Disorder in A Nationally Representative Sample. Depression And Anxiety, 16, 162-171.

Carver, C. S., Pozo, C., Harris, S. D., Noriega, V., Scheier, M. F., Robinson, D. S., ... ve Clark, K. C. (1993). How coping mediates the effect of optimism on distress: A study of women with early stage breast cancer. Journal of Personality and Social Psychology, 65(2), 375-390.

Carver, C. S., Scheier, M. F. ve Segerstrom, S. C. (2010). Optimism. Clinical psychology review, 30(7), 879-889.

Chang, E. C., Rand, K. L. ve Strunk, D. R. (2000). Optimism and risk for job burnout among working college students: Stress as a mediator. Personality and Individual Differences, 29(2), 255-263.

Çakır, Z. (2016). Sıkıntıya Toleranssızlık Ölçeği ve Bilişsel-Davranışsal Kaçınma Ölçeğinin psikometrik özelliklerinin incelenmesi. Anadolu Psikiyatri Dergisi, 17(1), 24-32.

Çobaner, A. A. (2013). Sağlık iletişiminde korku öğesinin kullanımı: sigara paketlerinde kullanılan sigara karşıtı görsellerin göstergebilimsel analizi. İletişim Kuram ve Araștırma Dergisi, (37).

Darvill, T. J. ve Johnson, R. C. (1991). Optimism and perceived control of life events as related to personality. Personality and Individual Differences, 12(9), 951-954.

Dolinski, D., Dolinska, B., Zmaczynska-Witek, B., Banach, M. ve Kulesza, W. (2020). Unrealistic Optimism in the Time of Coronavirus Pandemic: May It Help to Kill, If So-Whom: Disease or the Person? Journal of Clinical Medicine, 9(5), 1464.

Dönmez, İ., ve Gürbüz, S. (2020). Üniversite Öğrencilerinin Covid-19 Virüsü Hakkında Bilişsel Yapılarının Belirlenmesi. MANAS Sosyal Arasttrmalar Dergisi, 9(4), 2159-2172.

Dumalaon-Canaria, J. A., Prichard, I., Hutchinson, A. D. ve Wilson, C. (2018). Fear of cancer recurrence and psychological well-being in women with breast cancer: The role of causal cancer attributions and optimism. European journal of cancer care, 27(1), e12579.

Ganson, K. T., Weiser, S. D., Tsai, A. C. ve Nagata, J. M. (2020). Associations between Anxiety and Depression Symptoms and Medical Care Avoidance during COVID-19. Journal of General Internal Medicine, 1-3.

Geers, A. L., Wellman, J. A., Seligman, L. D., Wuyek, L. A. ve Neff, L. A. (2010). Dispositional optimism, goals, and engagement in health treatment programs. Journal of Behavioral Medicine, 33(2), 123-134.

Gillham J. ve Reivich, K. (2004). Cultivating Optimism in Childhood and Adolescence. Annals of the American Academy of Political and Social Science, (591), 146-163. 
Goodwin, R., Gaines Jr, S. O., Myers, L. ve Neta, F. (2011). Initial psychological responses to Swine Flu. International Journal of Behavioral Medicine, 18(2), 88-92.

Goyal, K., Chauhan, P., Chhikara, K., Gupta, P. ve Singh, M. P. (2020). Fear of COVID 2019: First suicidal case in India. Asian Journal of Psychiatry, 49, 101989.

Haktanır, A., Seki, T. ve Dilmaç, B. (2020). Adaptation and evaluation of Turkish version of the fear of COVID-19 scale. Death Studies, 1-9.

Harper, C. A., Satchell, L. P., Fido, D. ve Latzman, R. D. (2020). Functional fear predicts public health compliance in the COVID-19 pandemic. International journal of mental health and addiction.

Hatun, O., Dicle, A. N. ve Demirci, İ. (2020). Koronavirüs Salgınının Psikolojik Yansımaları ve Salgınla Başa Çıkma. Turkish Studies, 15, 4.

Huang, J. Z., Han, M. F., Luo, T. D., Ren, A. K. ve Zhou X. P. (2020). Mental health survey of 230 medical staff in a tertiary infectious disease hospital for COVID-19. Chinese journal of industrial bygiene and occupational diseases, 38.

Ingledew, D. K. ve Brunning, S. (1999). Personality, preventive health behaviour and comparative optimism about health problems. Journal of Health Psychology, 4(2), 193-208.

Ji, L. J., Zhang, Z., Usborne, E. ve Guan, Y. (2004). Optimism across cultures: In response to the severe acute respiratory syndrome outbreak. Asian Journal of Social Psychology, 7(1), 25-34.

Kabakaş, K. (2018). Kanser hastalarna bakim veren bireylerde ölüm korkusu, kansere yakalanma korkusu ve sağhlk anksiyetesi düreyleri. (Yüksek Lisans Tezi). Üsküdar Üniversitesi Sosyal Bilimler Enstitüsü, İstanbul.

Kahleoğulları, G. (2017). Hayatta Amaç Ölçeği, Hayatta Anlam Anketi ve Yașam Yönelimi Testi Revize Türkçe versiyonunun geçerlik, güvenirliği ve faktör yapısı. (Yüksek Lisans Tezi). Hasan Kalyoncu Üniversitesi Sosyal Bilimler Enstitüsü, Gaziantep.

Khan, S., Siddique, R., Li, H., Ali, A., Shereen, M. A., Bashir, N. ve Xue, M. (2020). Impact of coronavirus outbreak on psychological health. Journal of Global Health, 10(1).

Kilıç, S. (2016). Cronbach's alpha reliability coefficient. Psychiatry and Behavioral Sciences, 6(1), 47.

Kırpık, G. (2020). COVID-19 Pandemisinin İnsan Kaynakları Üzerindeki Etkisinin Akademi, Medya ve İş Dünyası Perspektifinden İncelenmesi. MANAS Sosyal Araştırmalar Dergisi, 9(4), 2393-2406.

Kivimäki, M., Vahtera, J., Elovainio, M., Helenius, H., Singh-Manoux, A. ve Pentti, J. (2005). Optimism and pessimism as predictors of change in health after death or onset of severe illness in family. Health psychology, 24(4), 413.

Lee, S. A. (2020). Coronavirus Anxiety Scale: A brief mental health screener for COVID-19 related anxiety. Death studies, 44(7), 393-401.

Leppin, A. ve Aro, A. R. (2009). Risk perceptions related to SARS and Avian Infl uenza: Theoretical foundations of current empirical research. International Journal of Behavioral Medicine, 16, 7-29.

Lima, C. K. T., de Medeiros Carvalho, P. M., Lima, I. D. A. S., de Oliveira Nunes, J. V. A., Saraiva, J. S., de Souza, R. I., ... ve Neto, M. L. R. (2020). The emotional impact of Coronavirus 2019-nCoV (new Coronavirus disease). Psychiatry research, 112915.

Mamun, M. A. ve Griffiths, M. D. (2020). First COVID-19 suicide case in Bangladesh due to fear of COVID-19 and xenophobia: Possible suicide prevention strategies. Asian Journal of Psychiatry.

Mansfield, P. R. (2007). The illusion of invulnerability. BMJ, 334(7602), 1020-1020. Erişim Adresi: https://www.researchgate.net/publication/6322620_The_illusion_of_invulnerability

Mazlum, F, ve Mazlum, Ö. (2014). Sigara paketlerinin üzerindeki görsel ve sözel uyarı mesajlarının üniversite öğrencileri üzerindeki etkisinin incelenmesi ve yeni öneriler. Fine Arts, 9(1), 12-32.

Mertens, G., Gerritsen, L., Duijndam, S., Salemink, E. ve Engelhard, I. M. (2020). Fear of the coronavirus (COVID19): Predictors in an online study conducted in March 2020. Journal of Anxiety Disorders, 102258.

Nes, L. S. ve Segerstrom, S. C. (2006). Dispositional Optimism and Coping: A Meta-Analytic Review. Personality and Social Psychology Review, 10(3), 235-251.

Newman, M. G. ve Llera, S. J. (2011). A novel theory of experiential avoidance in generalized anxiety disorder: A review and synthesis of research supporting a contrast avoidance model of worry. Clinical psychology review, 31(3), 371-382.

Ottenbreit, N. D. ve Dobson, K. S. (2004). Avoidance and depression: the construction of the Cognitive-Behavioral Avoidance Scale. Behaviour research and therapy, 42(3), 293-313.

Pakpour, A. H. ve Griffiths, M. D. (2020). The fear of COVID-19 and its role in preventive behaviors. Journal of Concurrent Disorders.

Puskar, K. R., Sereika, S. M., Lamb, J., Tusaie-Mumford, K. ve McGuinness, T. (1999). Optimism and its relationship to depression, coping, anger, and life events in rural adolescents. Issues in mental health nursing, 20(2), 115-130.

Raude, J., Debin, M., Souty, C., Guerrisi, C., Turbelin, C., Falchi, A., ... ve Colizza, V. (2020). Are people excessively pessimistic about the risk of coronavirus infection?. Psy ArXiv Preprints. 10.31234/osf.io/364qj

Rogers, R. W. (1985). Attitude Change and Information Integration in Fear Appeals. Psychological Reports, 56(1), 179_ 182.

Sadedil, S. N. K. (2016). Pazarlama mesajlarının etkinliği açısından geleneksel pazarlama araştırmaları ile nöropazarlama araştırmalarının karşılaştırılması;"sigara paketleri üzerindeki caydırıcı mesajların, sigara kullanma alışkanlıkları üzerindeki etkisi”. (Doktora Tezi). Marmara Üniversitesi Sosyal Bilimler Enstitüsü, İstanbul. 
Scheier, M. F. ve Carver, C. S. (1985). Optimism, coping and health: Assessment and implications of generalized outcome expectancies. Health Psychology, 4, 219-247.

Scheier, M. F. ve Carver, C. S. (2002). Optimism, İçinde Snyder, C. R., Lopez, S. J. (Edt) Handbook of Positive Psychology (ss. 231-243). New York: Oxford University Press.

Scheier, M. F., Carver, C. S. ve Bridges, M. W. (1994). Distinguishing optimism from neuroticism (and trait anxiety, self-mastery, and self-esteem): A reevaluation of the Life Orientation Test. Journal of Personality and Social Psychology, 67, 1063-1078.

Seçer, I. ve Ulaş, S. (2020). An Investigation of the Effect of COVID-19 on OCD in Youth in the Context of Emotional Reactivity, Experiential Avoidance, Depression and Anxiety. International Journal of Mental Health and Addiction, 1-14.

Seligman, M. E. ve Schulman, P. (1986). Explanatory style as a predictor of productivity and quitting among life insurance sales agents. Journal of personality and social psychology, 50(4), 832.

Shabahang, R. (2020). Cognitive behavioural intervention for health anxiety, somatosensory amplification, and depression in coronavirus disease 2019 anxiety: an interventional study in Iran. Psychiatria Psychologia Kliniczna, 20, 87-93.

Sivri, F. Z. (2019). Yetişkinlerde affedicilik, iyimserlik ve öznel zindelik arasindaki ilişkinin incelenmesi. (Yüksek Lisans Tezi). Necmettin Erbakan Üniversitesi Eğitim Bilimleri Enstitüsü, Konya.

Sohrabi, C., Alsafi, Z., O’Neill, N., Khan, M., Kerwan, A., Al-Jabir, A., ... ve Agha, R. (2020). World Health Organization declares global emergency: A review of the 2019 novel coronavirus (COVID-19). International Journal of Surgery.

Steptoe, A., Wright, C., Kunz-Ebrecht, S. R. ve Iliffe, S. (2006). Dispositional optimism and health behaviour in community-dwelling older people: Associations with healthy ageing. British journal of health psychology, 11(1), 7184.

Sturman, L. S. ve Holmes, K. V. (1983). The molecular biology of coronaviruses. Advances in Virus Research, 28, 35112.

T.C. Sağlık Bakanlığı Halk Sağlığ1 Genel Müdürlüğü. (2020). COVID-19 (SARS-CoV-2 Enfeksiyonu) Genel Bilgiler Epidemioloji ve Tanı (1 Haziran 2020). Erişim Adresi: https://www.tahud.org.tr/file/cdd0219d-4c17-4460ade3-0b0aad742c0b/COVID-19_REHBERI_GENEL_BILGILER_EPIDEMIYOLOJI_VE_TANI.pdf

Tannenbaum, M. B., Hepler, J., Zimmerman, R. S., Saul, L., Jacobs, S., Wilson, K. ve Albarracín, D. (2015). Appealing to fear: A meta-analysis of fear appeal effectiveness and theories. Psychological Bulletin, 141(6), 11781204.

Tennen, H. ve Affleck, G. (1987). The costs and benefits of optimistic explanations and dispositional optimism. Journal of personality, 55(2), 377-392.

Thakur, V. ve Jain, A. (2020). COVID 2019-suicides: A global psychological pandemic. Brain, behavior, and immunity. $88,952-953$.

TÜBA. (2020). COVID 19 pandemi değerlendirme raporu. Ankara: Türkiye Bilimler Akademisi. Erişim adresi: http://www.tuba.gov.tr/files/images/2020/kovidraporu/Covid-19\%20Raporu-Final+.pdf

Wang, C., Pan, R., Wan, X., Tan, Y., Xu, L., Ho, C. S. ve Ho, R. C. (2020). Immediate psychological responses and associated factors during the initial stage of the 2019 coronavirus disease (COVID-19) epidemic among the general population in China. International journal of environmental research and public health, 17(5), 1729.

Williams, K. C. (2012). Fear appeal theory. Research in Business and Economics Journal, 5(1), 1-21.

Wise, T., Zbozinek, T., Michelini, G., Hagan, C. C. ve Mobbs, D. (2020). Changes in risk perception and protective behavior during the first week of the COVID-19 pandemic in the United States. PsyArXiv Preprints.10.31234/osf.io/dz428.

Wittchen, H-U. (2002). Generalized Anxiety Disorder: Prevalence, Burden, And Cost to So-crety. Depression And Anxiety, 16, 162-171.

World Health Organization. (2020a). WHO Director-General's opening remarks at the media briefing on COVID-19 - 11 March 2020. Erişim Adresi: https://www.who.int/dg/speeches/detail/who-director-general-s-openingremarks-at-the-media-briefing-on-covid-19---11-march-2020

World Health Organization. (2020b). Considerations in adjusting public health and social measures in the context of COVID-19, WHO/2019-nCoV/Adjusting_PH_measures/2020.1.

Erişim

Adresi: https://apps.who.int/iris/bitstream/handle/10665/331773/WHO-2019-nCoV-Adjusting_PH_measures2020.1-eng.pdf?sequence $=1$ \&isAllowed $=\mathrm{y}$.

Wu, K. K., Chan, S. K. ve Ma, T. M. (2005). Posttraumatic stress, anxiety, and depression in survivors of severe acute respiratory syndrome (SARS). Journal of Traumatic Stress: Official Publication of The International Society for Traumatic Stress Studies, 18(1), 39-42.

Zandifar, A. ve Badrfam, R. (2020). Iranian mental health during the COVID-19 epidemic. Asian Journal of Psychiatry, $51,101990$.

Zimmermann, M., Bledsoe, C. ve Papa, A. (2020). The Impact of the COVID-19 Pandemic on College Student Mental Health: A Longitudinal Examination of Risk and Protective Factors. PsyArXiv Preprints. 10.31234/osf.io/2y7hu. 


\section{EXTENDED ABSTRACT}

The pandemic and the changes that brought along have also affected the mental health of individuals. It is known that the fear of coronavirus can affect the response of individuals to the pandemic and this can cause them to make irrational decisions. The main purpose of this research is to determine the predictive power of cognitive behavioral avoidance and life orientation of on coronavirus fear. In addition, another main purpose of the study is to examine various factors that may be related to these three variables.

Optimism is defined as expecting the best result in the encountered situations and looking forward to the future with confidence. In the literature, it is seen that the optimism is discussed that as a protective personality trait (Benson, 2007). On the other hand, there are researchers who claim that the excessive optimism and unrealistic optimism may pose various risks as they prevent the formation of some precautionary behaviors. In this direction, there are many studies that show that there is a negative relationship between optimism and preventive behaviors (Burger \& Burns, 1988). On the other hand, Tennen and Ameck (1987) suggested that the excessive optimism may cause the individuals to see the possibility of something bad to him lower than the compared to other people and put forth the drawbacks of excessive optimism. In this context, it is stated that this situation, which is called the illusion of invulnerability, can prevent the behaviors that may be necessary in daily life (Mansfield, 2007).

It is known that avoidance plays a significant role in the origin or maintenance of anxiety and phobias. Avoidance defined as moving away from an action, situation, environment or various things that disturbing the individuals. Both cognitive and behavioral avoidance that is trying not to think about the situation that causes anxiety or fear, or getting away from that environment, allows the individual to get away from these feelings for a short term and this situation can lead to the reinforcement of this behavior. Although avoidance brings a sense of relief to the individual for a short term, it causes the maintenance or even increase of the anxiety and fear in the long term.

For the aim of the study "Covid-19 Fear Scale (FCV-19S)", "Life Orientation Test Revised (LOTR)", Cognitive Behavioral Avoidance Scale (CBAS)" and "Personal Information Form" were used in order to obtain data. The study group occurs from the over the age of 18, 411 contender who volunteered to participate the research from the 63 provinces of Turkey in the COVID-19 outbreak. \%55 of the participants $(n=226)$ are female participants and $\% 45$ of the participants $(n=185)$ are male participants. The average age of the participants the study is calculated as 31.9. Participants are spent 15 minute average to answer all questions. In order to examine the data collected as online, T Test, Pearson Moments Correlation Coefficient, and Multiple Regression analyzes were performed by SPSS.

The result of the T Test that made in this study, it is understood that the coronavirus fears and the level of thinking that they can be treated in the hospital due to the coronavirus differs significantly depending on whether there is a relatives who are treated in the hospital due to coronavirus. It is also possible to say that the female participants have higher levels of Covid-19 fear than the man who participate the study. In addition to this, the participants who witnessed the treatment process had higher levels of compliance to the precautions than those who did not. It was found that the participants who regularly followed up the case numbers and the explanations of the doctors had higher Covid-19 Fear Scale scores compared to those who did not; they thought that they could receive treatment due to coronavirus more frequently and the level of compliance to the precautions was higher. Pearson Product Moment Correlation Coefficient was used to determine the relationships between the variables examined within the scope of the study. When the relationship between the compliance levels of main precautions (hand hygiene, social distance, mask using) and the total points that the participants take from Covid-19 Fear Scale examined, it was seen that there was a statistically significant, positive way and low level relationship. When looking to the relationship between life orientation scale total scores of participants and the total scores from that they have from the cognitive behavioral avoidance scale, it was found that there is a statistically significant, negative way and mid-level relationship. Moreover, it was observed that there was a statistically significant, negative way and low level relationship between the scores of the participants that they have from the Life Orientation Scale and Covid-19 Fear Scale. So, as the pessimism level of the participants increases, their fear of coronavirus decreases. Additionally, it was found that there was a statistically significant, positive, and mid-level relationship between the scores that participants got from Cognitive-Behavioral Avoidance Scale and Covid-19 Fear Scale. Finally, it was found that the 
individuals' life orientation and cognitive-behavioral avoidance significantly predicted the coronavirus fears of them and explains the $\% 11$ of the changes in coronavirus fears.

With the increase of fear of Covid-19 it is an expected result that preventive behaviors will also increase. But in cases where fear is extremely intense, it may cause individuals to display various incompatible behaviors other than the recommended precautions (Ahorsu, 2020). For this reason, it is important for individuals to know the effectiveness of the ways that they try to protect against the virus. In providing necessary psychological assistance services to individuals, it may be beneficial for experts working in the field to consider the relationships revealed in this study. More research is needed on the causality relationships between mentioned variables. In addition to this, it is possible to say that conducting studies with wider participation may be beneficial. 